\title{
The Implementation of Fusion Food Teaching Materials Based on Local Bali Food in Vocational High School Students in Culinary Expertise
}

\author{
N W Sukerti ${ }^{1, *}$ Cok Istri R. Marsiti ${ }^{1}$ Luh Masdarini $^{1}$ Damiati Damiati $^{1}$ \\ ${ }^{1}$ Vocational Education and Culinary Arts Study Program, Faculty of Engineering and Vocational Studies, Undiksha. \\ "Corresponding author.Email: wayan.sukerti@undiksha.ac.id
}

\begin{abstract}
The present study aimed at describing (1) the results of the implementation of local food teaching materials seen from the students' practical learning outcomes, (2) learning tools starting from the student worksheet and learning videos on the basic competency of fusion food for the $12^{\text {th }}$ grade students of Vocational High School in Buleleng Regency, (3) students' responses toward local food teaching materials used in the $12^{\text {th }}$ grade learning fusion food. Teaching materials can facilitate students to explore the material for developing fusion food learning. Furthermore, the obstacle in the development and use of local food teaching materials, namely the COVID-19 pandemic condition which makes it impossible to present students as a whole in class. This research was developmental research using the ADDIE model. The subjects of this research were teachers, research team, and students. The number of respondents were 36 people. Data were collected by conducting observation and questionnaire methods. Data were analyzed by using descriptive analysis technique. The results of study showed that: (1) the implementation of local food teaching materials through practical learning activities of Fusion Food at four vocational schools in Buleleng district could be declared successful based on the results of the students' practice performance assessment on each dish considering 4 aspects, namely aspects of color, taste, texture, and presentation. The salad dish with an average score of 3.78 was categorized into good category, soup with an average score of 3.80 was categorized into a good category, the main course with a score of 3.77 was categorized into a good category, and dessert with a score of 3.72 was categorized into a good category, (2) the fusion food learning tools had been arranged based on local Balinese food ingredients, starting from the students' worksheet and food learning media (learning videos), (3) students' responses to teaching materials used as teaching materials to support practical activities were positive.
\end{abstract}

Keywords: Teaching Material, Local Food, Balinese Fusion Food Skills.

\section{INTRODUCTION}

Local food learning should include some learning activities and materials to improve the competency of knowledge, skills, and attitudes based on local wisdom that can elevate the nation's culture. In food learning materials, activities related to the realm of real work are designed, namely (1) food processing works, (2) food performance works, and (3) local resource-based food business works. Especially, the food problem in vocational school has not been discussed, examined, even practiced by the teachers and students.

Teenagers should have the ability to provide local food for themselves, present innovative local food, and have the ability of local food entrepreneurs in a simple way. Therefore, this developmental research is really needed, so that teenagers as the younger generation realize and support the food self-sufficiency program, through the preservation of Balinese culinary specialties, as well as increasing food security.

One of the basic competencies (BC) that must be achieved in learning at public vocational school (SMKN) in the field of culinary expertise is analyzing and practicing Fusion food. These basic competencies are found in food processing and serving subjects.

The basic competency of 3.24 and 4.24 appear in the $12^{\text {th }}$ grade in the odd semesters. One of the important materials to be included in the BC Fusion food is the Fusion food material based on local food. This is interesting because Bali is rich with natural 
resources that can be packaged in Fusion food material, based on local food, so that the uniqueness of this teaching material can be disseminated to the public through students' practicum of Fusion food.

One of the efforts to improve the quality of education is to carry out various educational program innovations, including; improvement of curriculum, procurement of books/teaching materials, improvement of the quality of teachers, and education personnel through various trainings, improvement of education management, improvement of educational facilities and infrastructure. The basic competency of fusion food is to develop knowledge and practice life skills based on art, technology, and economy. This learning begins with practicing creative-expression skills to express ideas and create an innovative food product by combining existing recipes, adding, reducing both main ingredients and other ingredients, so that a new and rationalized product can be created technologically as well as these skills lead to an appreciation of renewable technology, ergonomic, and applicable results in utilizing the surrounding environment by paying attention to its impact on the ecosystem, management, and economy [1]. Based on the explanation above, so this study is very urgent, because the ability of students through practical learning outcomes in processing fusion dishes made from local Balinese food can be known from the implementation of fusion food teaching materials [2].

Nowadays, local food learning has not been included in the curriculum at various school levels such as Elementary School, Junior High School, Senior High School, and also Vocational High School. Local food learning with local culinary adaptations should be given at the school level as an effort to introduce local food potential for self-reliance and regional/national food security. Considering that learning resources related to local food and processing methods are still very limited, one of the efforts that can be done is through the development of a learning device in the form of textbooks as a source of learning for teachers and students. The material contained in the textbook is arranged systematically and easily understood by students related to local food processing efforts with fusion food techniques, so it can produce traditional dishes that meet international presentation standards. Currently, the fusion food technique is becoming a trend or choice because it provides more creative and innovative dishes to attract consumer tastes. [3] Teaching materials are one of the useful learning resources in the learning activities.

In addition, it can also be used as a handbook for students in learning activities at the university covering basic concepts, subject matter, examples of application in everyday life. The characteristics of good teaching material are 1) containing adequate and presented material systematically to achieve learning objectives; 2) the substance must be in line with the curriculum covering aspects of the objectives/competencies to be achieved, methods, and assessments used in the learning process; 3 ) it is arranged systematically with the rules of scientific writing; 4) using familiar language that is easily understood and mastered by students, so that it has a high degree of legibility; 5) using an attractive format and physical form of teaching materials; and 6) increasing the motivation of the readers to learn. The components of the textbook contain a summary, providing feedback, creating opportunities for students to practice, considering the need of students, and using a communicative language style.

\section{METHOD}

This developmental research method used (Research \& Development) assisted by ADDIE model developed by [4] (The test subjects at the implementation stage were 4 researchers, 12 teachers, and 20 students. In this study, the researchers conducted an evaluation on students' practicum outcomes along with teacher of fusion subjects in each school. This study was carried out based on the predetermined schedule. Furthermore, students were asked to respond to the teaching materials used in learning. Data were collected through performance implementation which consisted of 1) product evaluation data from aspects of taste, color, shape, and presentation, 2) second stage evaluation data was data from the responses of vocational school students in limited quantities. The instruments for data collection were in the form of observation sheets, namely observation sheets based on the aspects being assessed, covering the aspects of taste, color, shape and presentation. Furthermore, questionnaires were distributed to students to collect students' responses toward the implemented teaching materials. The data analysis technique was carried out by grouping all information from qualitative data, in the form of input, feedback, criticism, and suggestions for improvement which were obtained from filling out the questionnaire. The results of the analysis and obtained data were used to improve the developed teaching material products.

The stages of development research in the second year consisted of the implementation stage and the evaluation stage. The research stage included the preparation stage covering orientation activities on the development of textbooks, coordination with teachers in charge of food processing, and food presentation in the basic competency of Fusion Food, who were served as partners as well as sources of information for textbook development, followed by the preparation of research instruments. 
The textbook development stage referred to the ADDIE developmental model, but the implementation in the second year consisted of two stages, namely the implementation stage and the evaluation stage.

\section{FINDINGS AND DISCUSSION}

\subsection{Findings}

The development of the Balinese Fusion Food textbook referred to the ADDIE model in the second year consisted of the implementation and evaluation stages as shown in Figure 1.

In this 2 nd year, the study was continued with the stage of implementing the results of the development of textbooks that had gone through reviews from several experts in their fields. For the implementation of this textbook, the research team collaborated with four public and private vocational schools in Buleleng district.

The four schools were: SMKN 1 Sukasada, SMKN 2 Singaraja, SMK Triatmajaya Singaraja and SMKN 1
Seririt. Before conducting the implementation in the form of student practicum, the research team held a focus group discussion (FGD) to share perceptions of the research activities that would be conducted. The following was the documentation during the FGD as seen in Figures 2 and 3.

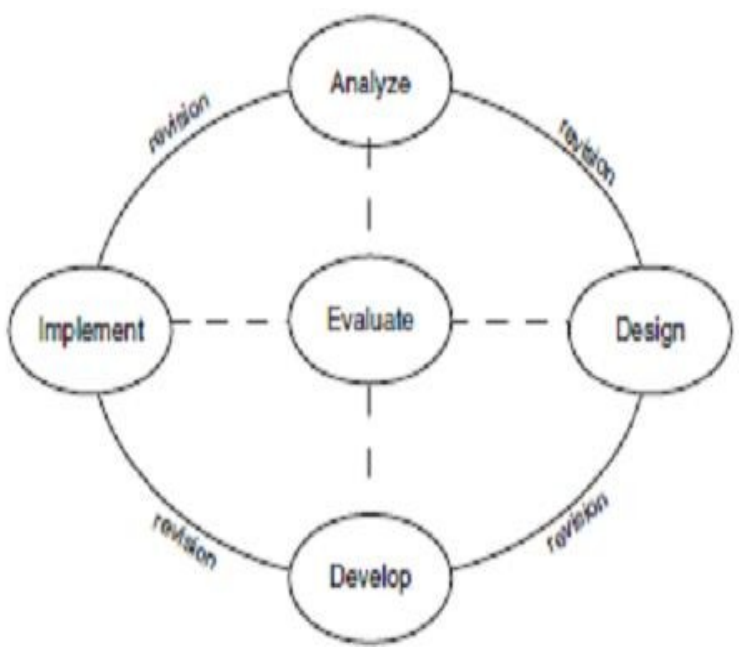

Figure 1. ADDIE Development Model Flow ([4])

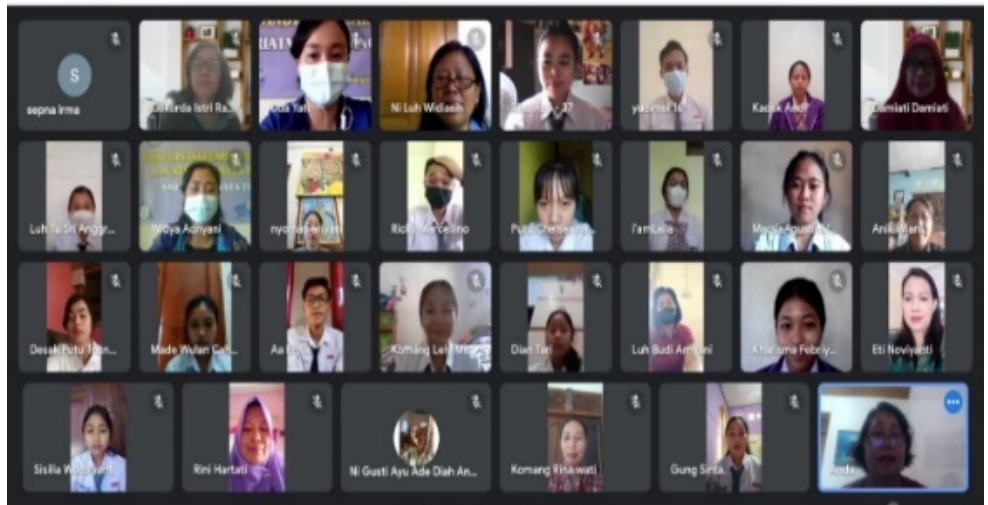

Figure 2. FGD sharing perception among teacher, students, and researcher team (Source: processed by researchers)

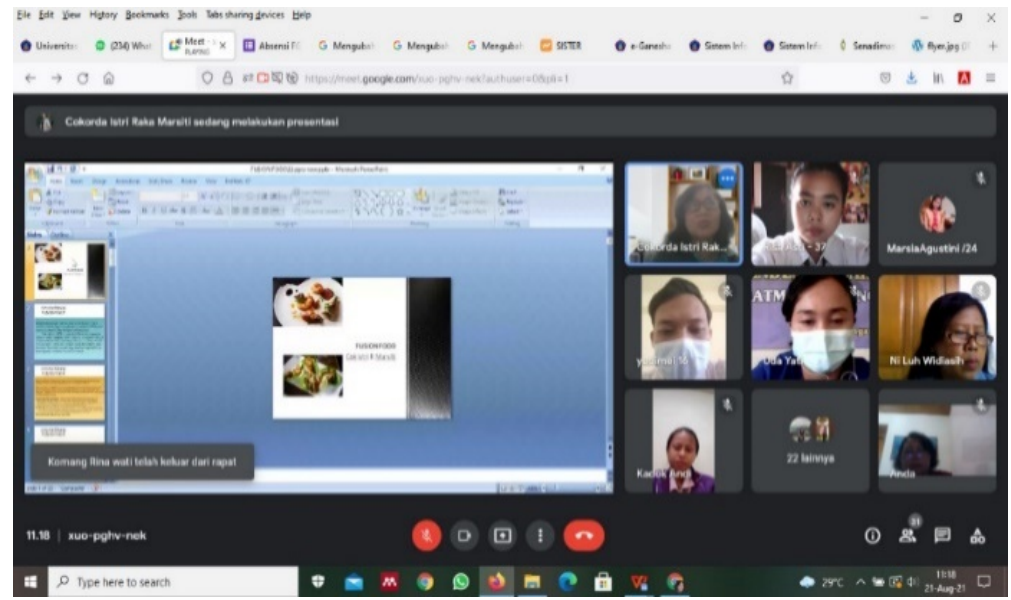

Figure 3. FGD with fusion food teachers (Source: processed by researchers) 
After the FGD implementation, practical activities were carried out in each school involving five students in each school. This step was taken considering the COVID-19 pandemic situation with the policy of Enforcement of Community Activity Restrictions, so that students were limited to only five people participating in practicum activities. The following are the results of student practicum activities as seen in Table 1.

Table 1. Results of Student Practicum Assessment with the theme of Fusion Food Based on Local Food

\begin{tabular}{|c|c|c|c|c|c|c|c|c|c|c|c|c|c|c|c|c|}
\hline \multirow{3}{*}{$\begin{array}{l}\text { Assess } \\
\text { ment }\end{array}$} & \multicolumn{16}{|c|}{ Dish } \\
\hline & \multicolumn{4}{|c|}{ salad } & \multicolumn{4}{|c|}{ soup } & \multicolumn{4}{|c|}{ main course } & \multicolumn{4}{|c|}{ dessert } \\
\hline & $\begin{array}{l}\text { col } \\
\text { or }\end{array}$ & $\begin{array}{l}\text { tas } \\
\text { te }\end{array}$ & $\begin{array}{l}\text { text } \\
\text { ure }\end{array}$ & $\begin{array}{l}\text { present } \\
\text { ation }\end{array}$ & $\begin{array}{l}\text { col } \\
\text { or }\end{array}$ & $\begin{array}{l}\text { tas } \\
\text { te }\end{array}$ & $\begin{array}{l}\text { text } \\
\text { ure }\end{array}$ & $\begin{array}{l}\text { present } \\
\text { ation }\end{array}$ & $\begin{array}{l}\text { col } \\
\text { or }\end{array}$ & $\begin{array}{l}\text { tas } \\
\text { te }\end{array}$ & $\begin{array}{l}\text { text } \\
\text { ure }\end{array}$ & $\begin{array}{l}\text { present } \\
\text { ation }\end{array}$ & $\begin{array}{l}\text { col } \\
\text { or }\end{array}$ & $\begin{array}{l}\text { tas } \\
\text { te }\end{array}$ & $\begin{array}{l}\text { text } \\
\text { ure }\end{array}$ & $\begin{array}{l}\text { present } \\
\text { ation }\end{array}$ \\
\hline 1 & 4 & 3 & 3 & 4 & 4 & 3 & 3 & 4 & 3 & 3 & 3 & 4 & 4 & 3 & 3 & 3 \\
\hline 2 & 4 & 4 & 3 & 4 & 4 & 4 & 3 & 4 & 3 & 4 & 4 & 4 & 4 & 3 & 3 & 4 \\
\hline 3 & 4 & 4 & 3 & 4 & 4 & 4 & 3 & 4 & 3 & 4 & 4 & 4 & 4 & 3 & 3 & 4 \\
\hline 4 & 4 & 4 & 3 & 4 & 4 & 4 & 3 & 4 & 4 & 4 & 3 & 4 & 3 & 3 & 3 & 4 \\
\hline 5 & 4 & 3 & 3 & 4 & 4 & 3 & 3 & 4 & 4 & 3 & 3 & 3 & 4 & 3 & 3 & 4 \\
\hline 6 & 4 & 3 & 4 & 4 & 4 & 3 & 4 & 4 & 4 & 3 & 4 & 3 & 4 & 3 & 4 & 4 \\
\hline 7 & 4 & 3 & 4 & 4 & 4 & 3 & 4 & 4 & 4 & 3 & 4 & 4 & 4 & 3 & 4 & 3 \\
\hline 8 & 4 & 4 & 4 & 4 & 4 & 4 & 4 & 4 & 4 & 4 & 4 & 4 & 3 & 4 & 4 & 4 \\
\hline 9 & 4 & 4 & 4 & 4 & 4 & 4 & 4 & 4 & 4 & 4 & 4 & 4 & 4 & 4 & 4 & 4 \\
\hline 10 & 4 & 4 & 4 & 4 & 4 & 4 & 4 & 4 & 4 & 4 & 4 & 4 & 4 & 4 & 4 & 4 \\
\hline 11 & 4 & 4 & 4 & 4 & 4 & 4 & 4 & 4 & 4 & 4 & 4 & 4 & 4 & 4 & 4 & 4 \\
\hline 12 & 4 & 4 & 3 & 4 & 4 & 4 & 3 & 4 & 4 & 4 & 3 & 4 & 4 & 4 & 3 & 4 \\
\hline 13 & 4 & 4 & 3 & 4 & 4 & 4 & 3 & 4 & 4 & 4 & 3 & 4 & 4 & 4 & 3 & 4 \\
\hline 14 & 4 & 3 & 4 & 4 & 4 & 3 & 4 & 4 & 4 & 3 & 4 & 4 & 4 & 3 & 4 & 4 \\
\hline 15 & 4 & 3 & 4 & 4 & 4 & 3 & 4 & 4 & 4 & 3 & 4 & 4 & 4 & 3 & 4 & 4 \\
\hline 16 & 4 & 3 & 4 & 4 & 4 & 3 & 4 & 4 & 4 & 3 & 4 & 4 & 4 & 3 & 4 & 4 \\
\hline total & 64 & 57 & 57 & 64 & 64 & 57 & 58 & 64 & 62 & 57 & 60 & 62 & 62 & 55 & 58 & 63 \\
\hline
\end{tabular}

On another side, the formula used for determining the mean of the data was adapted from [5]:

$$
M=\frac{\sum x}{N}
$$

Note :

$\mathrm{M}:$ The average quality test (aroma, texture, and test) $\sum x$ : The sum of each score (aroma, texture, and test)

$\mathrm{N}$ : The Number of Subjects (Sample)

Table 2. Average score and Indicator criteria

\begin{tabular}{|l|l|}
\hline \multicolumn{1}{|c|}{ Average Score } & Indicator Criteria \\
\hline $3,00-4,00$ & Good \\
\hline $2,00-2,99$ & Average \\
\hline $0,5-1,99$ & Not Good \\
\hline
\end{tabular}

In this study $M$ (mean) is the average of quality test which functions to determine the average aspects of colour, taste, texture, and presentation. Meanwhile $\sum \mathrm{x}$ is a score gained from the aspects of taste, texture, and presentation. $\mathrm{N}$ is the number of data that refers to the number of subject (sample) of this study which is 16 ratters.

The reference of decision making used in determining the quality level of fusion food products is seen from the aspect of color, aroma, texture and taste. The formula of conversion guidelines is used in the form of three scales that can be seen as follow:

\begin{tabular}{|l}
$\mathrm{M}_{\mathrm{i}}+1 \mathrm{SD}_{\mathrm{i}} \longrightarrow \mathrm{M}_{\mathrm{i}}+3 \mathrm{SD}_{\mathrm{i}}$ (Good) \\
$\mathrm{M}_{\mathrm{i}-1 \mathrm{SD}_{\mathrm{i}}} \longrightarrow \mathrm{M}_{\mathrm{i}}+1 \mathrm{SD}_{\mathrm{i}}$ (Average) \\
$\mathrm{M}_{\mathrm{i}-3 \mathrm{SD}_{\mathrm{i}}} \longrightarrow \mathrm{M}_{\mathrm{i}}-1 \mathrm{SD}_{\mathrm{i}}$ (Not Good)
\end{tabular}

Figures 4. The Conversation Guidelines Formula; 3 Scales; Source: [5].

Note :

$\mathrm{M}_{\mathrm{i}}$ : The Ideal Mean

$\mathrm{SD}_{\mathrm{i}}$ : The Ideal Deviation Standard 
Table 3. The Range of Average Score

\begin{tabular}{|l|c|c|}
\hline $\begin{array}{l}\text { Research } \\
\text { Aspect }\end{array}$ & Result & Category \\
\hline Color & 3,88 & Good \\
\hline Taste & 3,56 & Good \\
\hline Texture & 3,75 & Good \\
\hline Presentation & 3,88 & Good \\
\hline Mean & 3,77 & Good \\
\hline
\end{tabular}

The Formula of Determining The Ideal Mean and Ideal Deviation Standard

$$
\begin{aligned}
& \mathrm{M}_{\mathrm{i}}=\frac{1}{2}(\text { Maximal Score }+ \text { Minimum Score }) \\
& \mathrm{SD}_{\mathrm{i}}=\frac{1}{6}(\text { Maximal Score }+ \text { Minimum Score })
\end{aligned}
$$

Maximal Score $=4$

Minimum Score $=1$

Based on the formula above, the collected data will be converted and it presents the following results:

$\begin{array}{ll}\mathrm{M}_{\mathrm{i}} & =\frac{1}{2}(4+1) \\ \mathrm{M}_{\mathrm{i}} & =2,5 \\ \mathrm{SD}_{\mathrm{i}} & =\frac{1}{6}(4-1) \\ \mathrm{SD}_{\mathrm{i}} & =0,5\end{array}$

In addition, the reference of decision making used in determining the dregs tofu noodle is viewed from the aspect of aroma, texture, and taste based on the previous formula that can be shown from the table 2 .

Based on the previous formula, the results of the average calculation of each aspect are obtained as follows:

Table 4. The Product Assessment Result of Salad (Balinese Urab with Coconut)

\begin{tabular}{|l|c|c|}
\hline $\begin{array}{l}\text { Research } \\
\text { Aspect }\end{array}$ & Result & Category \\
\hline Color & 4,0 & Good \\
\hline Taste & 3,56 & Good \\
\hline Texture & 3,56 & Good \\
\hline Presentation & 4,0 & Good \\
\hline Mean & 3,78 & Good \\
\hline
\end{tabular}

Based on the results of the research above, it can be stated that the overall product quality started from salad with a mean score of 3.78 in the good category, Soup with a mean score of 3.80 in the good category, Main Course with a mean score of 3.77 in the good category and dessert with a mean score of 3.72 in the good category. Furthermore, students' responses to the textbooks that have been refined are displayed in the Table 7.
Table 5. The Product Assessment Result of Soup (Ares)

\begin{tabular}{|l|c|c|}
\hline $\begin{array}{l}\text { Research } \\
\text { Aspect }\end{array}$ & Result & Category \\
\hline Color & 4,0 & Good \\
\hline Taste & 3,57 & Good \\
\hline Texture & 3,62 & Good \\
\hline Presentation & 4,0 & Good \\
\hline Mean & 3,80 & Good \\
\hline
\end{tabular}

Tabel 6. The Product Assessment Result of Dessert (Crepe Laklak Cake).

\begin{tabular}{|l|c|c|}
\hline $\begin{array}{l}\text { Research } \\
\text { Aspect }\end{array}$ & Result & Category \\
\hline Color & 3,88 & Good \\
\hline Taste & 3,44 & Good \\
\hline Texture & 3,62 & Good \\
\hline Presentation & 3,94 & Good \\
\hline Mean & 3,72 & Good \\
\hline
\end{tabular}

\subsection{Discussion}

Based on the results of the research that had been described above, the implementation of the fusion food textbook through practicum carried out by Vocational High School students at 4 schools in Buleleng Regency could be declared successfully. The success could be seen from the average quality of each product started from salads, soups, main course and desserts with good category. Furthermore, in the preparation of learning instruments, the Student Worksheet had been successfully compiled, which was used as a guide in conducting the practicum. Furthermore, the student's response toward the fusion food learning in school was in a positive category. This success was inseparable from the students' discipline and focus on working by following the procedures that had been prepared. This finding was relevant to research results [4] [6] [7][8]

The textbook developmental research was only conducted through formative evaluation in collecting the data of each stage to be used as an improvement. The development of the Balinese Fusion Food textbook was conducted in order to assist teachers and facilitate students in the process of learning culinary skills related to fusion food techniques by highlighting local wisdom of traditional Balinese foods packaged as culinary products with international appearance. The textbook consisted of six chapters, namely Chapter I; Recognizing 
Table 7. The Questionnaire of Students' Responses on the Developed Textbook

\begin{tabular}{|l|c|c|c|c|}
\hline \multirow{2}{*}{\multicolumn{1}{|c|}{ Statements }} & \multicolumn{3}{c|}{ Student's Responses (\%) } \\
\cline { 2 - 4 } & Very Good & Good & Average & Not Good \\
\hline 1. The book's cover is interesting & 41,03 & 58,97 & 0 \\
\hline $\begin{array}{l}\text { 2. There is an harmony of the color, size, and layout } \\
\text { of the textbook }\end{array}$ & 28,21 & 64,10 & 7,69 & 0 \\
\hline 3. Having a clear instruction of each chapter & 53,85 & 43,59 & 2,56 & 0 \\
\hline 4. The font size and style used is readable & 56,41 & 41,03 & 2.56 & 0 \\
\hline 5. The language used is understandable & 48,72 & 51,28 & 0 & 0 \\
\hline 6. The Picture used is clear & 48,72 & 46,15 & 5,13 & 0 \\
\hline 7. The material description is traced & 25,64 & 71,79 & 2,56 & 0 \\
\hline $\begin{array}{l}\text { 8. I can understand the sentences dound in this } \\
\text { textbook }\end{array}$ & 38,46 & 53,85 & 7,69 & 0 \\
\hline 9. There is no sentence that has a double meaning & 17,95 & 76,92 & 5,13 & 0 \\
\hline $\begin{array}{l}\text { 10. The Exercise used is relevant to the learning } \\
\text { materials }\end{array}$ & 51,28 & 38,46 & 10,26 & 0 \\
\hline
\end{tabular}

Fusion Food, Chapter II; Traditional Balinese Culinary, Chapter III; Foods Decoration, Chapter IV; Balinese Appetizer with Fusion Technique, Chapter V; Balinese Main Course with Fusion Technique ; and Chapter VI; Balinese Dessert with Fusion Technique. The selected materials were based on the results of competence assessments required to the students as participants contained in the syllabus of the subjects, and the results of the learners' characteristics analysis related to the knowledge, attitudes, and skills which had been owned by the students which were about fusion food based on information from vocational high school teacher expertise in food and beverage. Therefore, the textbook was produced relevant to the students' needs and have a positive impact on the learning process. The topics of material that had been arranged were presented in the sequential learning units (Chapters) with a structured manner. The draft of the textbook preparation was carried out by an expert validation test to obtain a feasibility of its usage for students.

Based on the deployment of questionnaire responses that were given to 20 students in which it consisted of ten description items. The examination of the distribution percentages showed that they responded positively in the category of "good" and very good. Students provided some input and suggestions on the draft textbook and had been summarized as follows:

1) An interesting and better images were needed to attract the readers' interest in reading the textbook.

2) It is better to not use many colors on the cover to avoid a crowded impression.

3) The word "belayag" were replaced with "blayag"
4) The summary and the worksheet (assignments) were not combined to the material at the same page.

5) It was expected to provide more pictures of the material in order to make the readers could understand the material easily.

6) The font size might be magnified

7) It is better to provide an image related to the displayed materials regarding to the techniques of making garnish.

Based on the suggestion given by the experts, practitioners and students, improvements and adjustments were required. The use of language styles in the description of explanations, providing illustrations/ examples and interpretations in communicative language were needed in which it would be easily digested and understood by students as the textbook users.

\section{CONCLUSION}

The textbook "Balinese Fusion Food" was referred to the Research and Development (R\&D) method. As a continuation of the development of the ADDIE model particularly in the fifth step called as the implementation of textbooks, the following results were obtained, such as;

1) The assessment result of students' performance in processing foods products started from salad, soup, main course and dessert obtained the quality of practice results in the good category, starting from the salad, soup, main course and dessert menu. 
2) The development of learning instruments in the form of Student Worksheets, and assessment performance instruments had been successfully compiled based on the established criteria.

3) Based on the students' responses to the deployment of the questionnaire responses consisted of ten items description, from the examination of the distribution percentages, it could be stated that the students gave positive responses to both categories.

\section{REFERENCES}

[1] H. Purwanti, "Praktik Berkreasi Hidangan Fusion," J. Ilm. WUNY, vol. 1, no. 2, pp. 1-9, 2019, doi: https://doi.org/10.21831/jwuny.v1i2.27586.

[2] H. I. Ekayani, N. . Sukerti, L. Masdarini, and Damiati, "Pengembangan Buku Ajar Pangan Lokal Untuk Meningkatkan Balinese Food Skills Pada Remaja SMK," in Senari 7, 2020, pp. 235-242.

[3] Mahmudi, "Pengembangan Bahan Ajar Matematika Dengan Pendekatan Kontekstual Untuk Pembelajaran Di Smk," 2019.

[4] R. M. 2009. I. U. U. of G. Branch, Instructional Design The ADDIE Approach (Serial Online). USA: University of Georgia, 2009.

[5] I. W. Koyan, Asesmen Dalam Pendidikan. 2011.

[6] A. Thalib, M. M., \& Munir, "Pengembangan Bahan Ajar Statistik Deskriptif Dengan Model ADDIE.," Pros. Semin. Nas., vol. 1, no. 1, pp. 2-11, 2021.

[7] A. Nurafni, H. Pujiastuti, and A. Mutaqin, "Pengembangan Bahan Ajar Trigonometri Berbasis Kearifan Lokal," J. Medives J. Math. Educ. IKIP Veteran Semarang, vol. 4, no. 1, p. 71, 2020, doi: 10.31331/medivesveteran.v4i1.978.

[8] R. A. H. Cahyadi, "Pengembangan bahan ajar berbasis ADDIE model.," Halaqa Islam. Educ. J., vol. 3, no. 1, pp. 35-42, 2019. 